\title{
CHARACTERISATION OF A PLEISTOCENE DEBRIS-AVALANCHE DEPOSIT IN THE TENTENIGUADA BASIN, GRAN CANARIA ISLAND, SPAIN
}

\author{
Lomoschitz, A. ${ }^{a}$, Hervás, J. ${ }^{b}$ Yepes, J.a, Meco, J. ${ }^{c}$
}

\begin{abstract}
a Departamento de Ingeniería Civil, Campus de Tafira, Universidad de Las Palmas de Gran Canaria, Las Palmas de Gran Canaria 35017, Spain

b Institute for Environment and Sustainability, Joint Research Centre (JRC), European Commission, Ispra 21027, Italy

c Departamento de Biología, Campus de Tafira, Universidad de Las Palmas de Gran Canaria, Las Palmas de Gran Canaria 35017, Spain
\end{abstract}

\begin{abstract}
We studied a large debris-avalanche deposit of Pleistocene age in the Tenteniguada Basin, Gran Canaria Island, Spain. This deposit, which is well preserved because it is mostly covered by basanite lava flows, has distinctive matrix and block facies, hummocky topography and internal structures typical of debris avalanches. However, neither syneruptive lavas nor some characteristic features of volcanic debris-avalanche deposits, such as a stratovolcano edifice or a horseshoe-shaped crater, are present. The occurrence of internal features characteristic of volcanic avalanche deposits could be attributed to the volcanic materials involved in the movement rather than to the triggering of the avalanche during a volcanic eruption. The conditioning factors are shown to be associated with specific structural and hydrological conditions, such as the presence of old volcanic domes, strength reduction of the rocks, effective stress decrease, active gully erosion and water table rise during Pleistocene humid episodes. We finally suggest that the possible triggering factor of the avalanche was a neighbouring volcanic or tectonic earthquake.
\end{abstract}

